\title{
Gökkuşağı Alabalıkları (Oncorhynchus mykiss, Walbaum 1792)'nda Vagokokkozise Karşı Etkili Antibakteriyel Tedavinin Belirlenmesi
}

\author{
Alper KAN ${ }^{1}$, Behire I. DİDİNEN ${ }^{2 *}$
}

${ }^{1}$ Süleyman Demirel Üniversitesi, Fen Bilimleri Enstitüsü, Isparta

${ }^{2}$ Süleyman Demirel Üniversitesi, Eğirdir Su Ürünleri Fakültesi, Isparta

Geliş : $\quad 12.02 .2016$

Kabul : $\quad 14.04 .2016$

*Sorumlu yazar: e-posta: behiredidinen@sdu.edu.tr

Basılı ISSN: 1300 - 4891E. Dergi ISSN: 1308 - 7517

Özet

Gökkuşağı alabalı̆̆ında (Oncorhynchus mykiss) Vagococcus salmoninarum patojeninin neden olduğu vagokokkozis, ülkemizde görülen ve ekonomik kayıplara neden olan bir bakteriyel hastalıktır. Bu çalışmada vagokokkozisin antibakteriyel ilaçlarla tedavi seçeneklerinin belirlenmesi amaçlanmıştır. $\mathrm{Bu}$ amaçla, $150 \mathrm{~g}$ ağırlığındaki gökkuşağı alabalığının kullanıldığ 15 grup oluşturulmuştur. Tüm gruplardaki balıklar deneysel olarak V. salmoninarum ile enfekte edilmiştir. Bakterinin balıklara enjeksiyonunu takiben, balıkların yemlerine 10 gün süreyle sıvı bitkisel yă̆ ile eritromisin $(100 \mathrm{mg} / \mathrm{kg}$ canlı ağırlık/gün), florfenikol $(10 \mathrm{mg} / \mathrm{kg}$ canlı ağırlık/gün), doksisiklin (20 mg/kg canlı ağılık/gün) ve amoksisillin $(80 \mathrm{mg} / \mathrm{kg}$ canlı ağırlık/gün) ilavesi yapılmıştır. Kontrol grubunun yemlerine sadece bitkisel yağ ilave edilmiştir. Tedavi esnasında ve sonrasında her grupta ölen balıklar kaydedildi ve Triptic Soy Agar kullanılarak bakteriyel incelemeler yapılmıştır. Deneme sonunda, tüm gruplardaki klinik bulgular, ölüm oranları ve balıklardan etkenin reizolasyon yüzdeleri dikkate alındığında, eritromisin ve amoksisillinin tedavi için yeterli etkinlik göstermedikleri görülmüştür. Florfenikol ve doksisiklin ise enfeksiyonu tedavi etmek için çok daha yüksek etkinlik göstermiştir.

Anahtar kelimeler: Gökkuşağı alabalığı, vagokokkozis, tedavi, antibiyotik

\section{Determination of Effectiveness of Antibacterial Treatment in Rainbow Trout Against Vagococcosis}

\begin{abstract}
Vagococcosis caused Vagococcus salmoninarum in rainbow trout (Oncorhynchus mykiss) in seen in ourcountryand it is a disease that causes economic losses. This study aimed to determine the choice of treatment with antibacterial drugs of vagococcosis. For this purpose, of 5 groups were formed using the rainbowtrout weighing $150 \mathrm{~g}$. Fish in all groups were experimentally infected with $V$. salmoninarum. Following bacterial injection into fish, erythromycin (100 mg / $\mathrm{kg}$ body weight / day), florfenicol (10 mg / $\mathrm{kg}$ body weight / day), doxycycline (20 mg / $\mathrm{kg}$ body weight / day) and amoxicillin ( $80 \mathrm{mg} / \mathrm{kg}$ body weight / day) were added to the fish feed with vegetableoil. Only vegetableoil was added to the feed of the control group. Mortalities were recorded during and after treatment in each group and bacteriological examination was performed using Triptic Soy Agar. When considered the clinical signs, mortality rates and reisolations percent in all groups, erythromycin and amoxicillin could not displayed enough efficacy. The florfenicol and doxycycline showed much higher activity to control the infection.
\end{abstract}

Keywords: Rainbow trout, vagococcosis, treatment, antibiotic

\section{GİRIŞ}

Kültürü yapılan sucul türlerin sayısında uluslararası bir artış eğilimi vardır. Bu nedenle son zamanlarda kültürü yapılan canlı türler arttıkça hastalık sayısında önemli bir artış meydana gelmiştir. Tatlı su ve deniz balıklarını etkileyen en önemli patolojik hastalıklardan biri de streptokokkozistir. Bu hastalık sistemiktir ve akuakültürde ciddi ekonomik kayıplardan sorumludur. 
Etiyolojik olarak streptecoccosis farklı cins ve türdeki Gram $(+)$ koklara ait pek çok etkenin neden olduğu hastalıkların bir kompleksi olarak tanımlanmıștır (Ruiz-Zarzuela vd., 2005).

Etiyolojik olarak, 'streptokokozis' Gram pozitif kokların farklı cins ve türlerini içeren pek çok etkenin neden olduğu hastalıklar için kullanılmaktadır. Klinik olarak bu enfeksiyonlar iki gruba ayrılmaktadır: $15^{\circ} \mathrm{C}$ 'nin üzerindeki sularda hem tatlı su hem de deniz balıkları için patojen olan kokların neden olduğu 1lık su enfeksiyonları ve $12^{\circ} \mathrm{C}$ 'nin altındaki su sıcaklıklarında yetiştirilen yalnızca salmonid balıklar için patojen olan kokların neden olduğu soğuk su enfeksiyonlarıdır (Ruiz-Zarzuela vd., 2005). Lactococcus garvieae, Streptecoccus iniae, S. agalactiae, $S$. parauberis'in neden olduğu 1l1k su enfeksiyonları kültürü yapılan tatlı su ve deniz balıkları için patojenik olan ve $15^{\circ} \mathrm{C}$ üzerindeki su sıcaklıklarında görülen enfeksiyonlardır. Soğuk su enfeksiyonları, $12^{\circ} \mathrm{C}$ altındaki su sıcaklıklarında sadece salmonid balıklar için patojeniktir. Soğuk su streptokoklarından olan Vagococcus salmoninarum, salmonidler için ciddi tehditler oluşturan kronik enfeksiyonlardan sorumlu Gram-pozitif bakteriler listesinde yer almaktadir (Michel vd.,1997).

Vagococcus salmoninarum, ciddi tehditler teşkil eden kronik enfeksiyonlardan sorumlu Gram-pozitif bakteriler listesinde yer almaktadır (Michel vd.,1997). Vagococcus salmoninarum' un meydana getirdiği vagokokkozis, Avrupa alabalik endüstrisinde (>150200 g) gökkuşağı alabalıklarında \%20-50 arası mortalite ile seyreden önemli bir bakteriyel hastalıktır. Salgınlar genelde su sicaklı̆̆1 $10-12^{\circ} \mathrm{C}$ olduğunda ve yumurtlama stresi sonucunda meydana gelebilmektedir (Michel vd., 1997; Ghittino vd., 2004; Ruiz-Zarzuela vd., 2005; Austin ve Austin, 2007). Hastalık ülkemizde 2011 yılında Akdeniz Bölgesi'ndeki bir çiftlikteki gökkuşağı alabalıklarında sağım sonrası stres sonucu görülmüş olup ölüm oranı \%50 olarak seyretmiştir (Didinen vd., 2011). Daha sonra balık nakilleriyle çiftlikler arasında yayılmış olup ülkemizde halen birçok çiftlikte görülmekte ve ekonomik kayıplara sebep olmaktadir.

Vagokokkosis hastalığı etkeni V. salmoninarum Avusturalya (Tazmanya), Fransa, İtalya, İspanya veTürkiye' deki gökkuşağı alabalıklarındaizole edilmiştir. V. salmoninarum anaç ve büyük balıklar için ciddi bir tehdit oluşturan ve kontrol prosedürlerine cevap vermeyen kronik infeksiyonlardan sorumlu Gram pozitif bakteriler içerisinde yer almaktadır.Vagokokkozis, yetişkin gökkuşağı alabalıklarında genelde su sıcaklığının 10$12^{\circ} \mathrm{C}$ olduğunda ve yumurtlama döneminde kaynaklanan stres sonucunda meydana gelmektedir (Michel vd., 1997; Ghittino vd., 2004; Ruiz-Zarzuela vd., 2005; Austin ve Austin, 2007; Didinen vd., 2011).

Vagokokkosis, ülkemizde 2011 yılından bu yana gökkuşağı alabalığı çiftliklerinde yavru, porsiyonluk ve anaç balıklarda görülmeye başlamış bir hastalıkhaline gelmiştir. Hastalığın neden olduğu ölüm oran1 \%80' e kadar ulaşabilmektedir. Akuakültürde Vagococcus salmoninarum salgınlarının önlenmesi için kullanılabilecek aşı mevcut değildir. Aşı çalışmaları yapılmış olmakla birlikte başarılı sonuçlar elde edilememiştir (Michel vd, 1997; Ruiz-Zarzuela vd., 2005). Ayrica V. salmoninarum in vitro olarak antibiyotiklere (ampisillin, amoksisillin, eritromisin, oksitetrasiklin ve doksisiklin) duyarli olmasına rağmen sahada tedavi uygulamalarında başarısızlık meydana geldiği bildirilmektedir (Michel vd, 1997; Ruiz-Zarzuela vd., 2005; Didinen vd., 2011). Buna karşın vagokokkozisin tedavisinde florfenikolün etkili olduğu belirtilmektedir (Tanrıkul vd., 2014).

$\mathrm{Bu}$ çalışmanın amacı, vagokokkozis hastalığını deneysel şartlarda oluşturarak tedavisinde eritromisin, amoksisillin, florfenikol ve doksisiklinin etkinliklerinin 
karşılaştırılmasıdır. Böylece, gökkuşağı alabalığı hastalıklarından biri olan vagokokkozisin tedavisinde etkili olacak antibiyotik ya da antibiyotikler seçilmiş olacaktır.

\section{MATERYAL ve YÖNTEM}

\section{Uygulama Yeri}

Çalışmada, $\mathrm{LD}_{50}$ dozunun belirlenmesi, deneysel enfeksiyon ve antibiyotikle tedavi uygulamaları SDÜ Eğirdir Su Ürünleri Fakültesi Alabalık Yetiştiricilik Tesisinin Balık Hastalıkları Biriminde gerçekleştirilmiştir. Balıklara, enjekte edilecek bakteri kültürün hazırlanması ve balıkların bakteriyolojik olarak incelenmesi Süleyman Demirel Üniversitesi Eğirdir Su Ürünleri Fakültesi Mikrobiyoloji Laboratuvarında yapılmıştır.

\section{Denemelerde Kullanılan Su Kaynağı ve Suyun Kalitesi}

Araştırmada kullanılan artezyen suyunun debisi 12 lt/dk, tanklardaki suyun ortalama sıcaklığ1 $12 \pm 2{ }^{\circ} \mathrm{C}$, pH’ s1 7,3 ve suda çözünmüş oksijen miktarı 7,4 mg/lt olarak ölçülmüştür.

\section{Deneysel Enfeksiyonun Oluşturulmasında Kullanılacak Vagococcus salmoninarum Suşu ve Reizolasyon Çalışması}

Denemede kullanılacak olan V. salmoninarum suşu 2011 yılında Eğirdir'de anaç balıklardan izole edilmiş ve $-80^{\circ} \mathrm{C}$ ' de saklanmıştır. $V$. salmoninarum suşu, ortalama 150 g ağırlığındaki 10 adet gökkuşağı alabalığına enjekte edilmiş $\left(5.26 \times 10^{7} /\right.$ balık dozunda) ve enjeksiyon sonrasındaki günlerde ölmek üzere olan balıklardan Triptik Soy Agar'a ekimler yapılarak $V$. salmoninarum'un reizolasyonu gerçekleşmiş ve böylece suşun virülensi artırılmıştır.

\section{V. salmoninarum'un $\mathrm{LD}_{50}$ Dozunun Belirlenmesi}

$\mathrm{LD}_{50}$ dozu belirlenmesinde, 20'şer adet $150 \mathrm{~g}$ ağırlığındaki gökkuşağı alabalıklarına steril fosfat buffer salin içerisinde $10^{7}$ ve $10^{8} \mathrm{cfu} /$ balık dozunda her gruptan 2 'şer paralel olacak şekilde balıklara enjeksiyon yapılmıştır. Kontrol grubuna $0,1 \mathrm{ml}$ PBS enjeksiyonu yapıld1. Ölümler 2 ay süreyle takip edilerek, balıkların \% 50' sini öldüren $\mathrm{LD}_{50}$ dozu belirlenmiştir.

\section{V. salmoninarum ile Deneysel Enfeksiyonun Oluşturulması}

Deneysel enfeksiyon denemesinde ortalama 150 g olan 200 adet gökkuşağı alabalığ1 kullanıldı. Balıklar, Isparta ili çevresindeki bir alabalık işletmesinden temin edildi. Deneme öncesi balıkların sağlık kontrolü amacıyla, 10 adet balıktan Tryptik Soy Agar(TSA)'a bakteriyolojik ekimler yapıldı.

Denemede, yaklaşık 400 lt hacmindeki yuvarlak fiberglas tanklara 5 grup 2'şer paralel olacak şekilde 20'şer balık yerleştirildi. Deneysel enfeksiyonun oluşturulmasında $V$. salmoninarum $\mathrm{LD}_{50}$ dozunda intraperitonal olarak balıklara enjekte edildi. Kontrol grubu balıklara steril PBS enjekte edildi. Enjeksiyondan sonra 2 ay süreyle balıklar takip edilerek ölüm oranları gözlendi. Ölümler olduğunda balıklardan TSA'ya ekim yapılarak spesifik ölümler araştırıldı. Nispi hayatta kalma oranları (RPS) aşağıdaki formül ile hesaplandı:

RPS $=$ [1-(Tedavi uygulaması yapılan balıklardaki mortalite $(\%) /$ Kontrol grubundaki mortalite (\%))] X 100 


\section{Antibiyotiklerle Tedavi}

Antibiyotiklerle tedavi uygulamalarına deneysel enfeksiyonun 8. gününde başlanmıştır. Kontrol grubu balıkların yemlerine sadece bitkisel yă ilave edildi. Diğer 4 grup balığın yemlerine sıvı bitkisel yağ ile eritromisin (100 mg/kg canlı ağırlık/gün), florfenikol (10 $\mathrm{mg} / \mathrm{kg}$ canlı ağırlık/gün), doksisiklin (20 mg/kg canlı ağırlık/gün) ve amoksisillin (80 mg/kg canlı ağırlık/gün) ilavesi yapıldı. Balıklar günlük olarak ağılıklarının \%1'i oranında ticari alabalık pelet yemi ile günde iki defa beslendi. Tedavi uygulamasına 10 gün devam edildi. Balıklar tedavi uygulaması sonra 40 gün süreyle takip edildi. Ölümler günlük olarak kaydedildi. Ölen balıklardan Tryptik Soy Agar'a ekim yapılarak $25^{\circ} \mathrm{C}$ 'de inkübasyon gerçekleştirildi ve spesifik ölümler araştırıldı. Deneme bitiminde gruplarda hayatta kalan balıkların tamamından ve kontrol grubu balıklarından ( 5 'er adet) reizolasyon yüzdelerinin tespiti için ekimler yapıldı.

\section{BULGULAR}

\section{V. salmoninarum'un Reizolasyonu Esnasında Elde Edilen Bulgular}

V. salmoninarum enjeksiyonu sonrasında, 3. günden itibaren balıklarda renkte koyulaşma, ekzoftalmus, yem alımında azalma, yavaş hareket etme gibi belirtiler gözlendi. Ölümler, enjeksiyonun 14. gününde başladı. Ölen balıklarda, bağırsaklarda sarı renkte sıv1 birikimi, karaciğerde büyüme ve solgunluk görüldü. Deneme boyunca ölümler 14-21 günler arasında gerçekleşti. Ölen balıklardan Tryptik Soy Agar'a ekimler yapılarak etkenin izolasyonu gerçekleştirildi. Yukarıdaki bulgular 1şığında, daha sonra yapılacak olan deneysel enfeksiyon uygulamasının 8. gününde antibiyotik tedavilerine başlanmaya karar verildi.

\section{Gökkuşağı Alabalıklarında $V$. salmoninarum'un LD50 Dozunun Belirlenmesi}

Gökkuşağ1 alabalıklarında $V$. salmoninarum'un $\mathrm{LD}_{50}$ dozunun belirlenmesi amacıyla iki farklı doz $\left(5,26 \times 10^{7}\right.$ ve $\left.1,8 \times 10^{7}\right)$ kullanılmıştır. Elde edilen balık ölümleri değerlendirildiğinde $V$. salmoninarum'un gökkuşağı alabalıklarındaki $L_{50}$ dozu $1.8 \times 10^{7} \mathrm{cfu} /$ bal1k olarak belirlenmiştir (Tablo1).

Tablo 1. Gökkuşağı alabalıklarında $V$. salmoninarum suşunun $\mathrm{LD}_{50}$ değerinin tespiti

\begin{tabular}{ccccc}
\hline \hline Balık Sayısı & $\begin{array}{c}\text { Ölen Balık } \\
\text { Sayısı }\end{array}$ & Ölüm \% & cfu/balık* & LD $_{50}$ ** \\
\hline 20 & 9 & 45 & $1.8 \times 10^{7}$ & \\
20 & 11 & 55 & $1.8 \times 10^{7}$ & $1.8 \times 10^{7}$ \\
20 & 8 & 40 & $5.26 \times 10^{6}$ & cfu/balık \\
20 & 8 & 40 & $5.26 \times 10^{6}$ & \\
\hline \hline
\end{tabular}

* cfu/balık : Her balığa verilen bakteri miktarı

** $\mathrm{LD}_{50}$ : Bir balık populasyonunun $\% 50$ ' ini öldürebilen doz 


\section{Deneysel Enfeksiyon Oluşturma ve Antibiyotiklerle Tedavi}

Deneysel enfeksiyon oluşturmak için grupların tamamındaki balıklara $\mathrm{LD}_{50}$ dozunda $\left(1,8 \times 10^{7} \mathrm{cfu} /\right.$ balık $)$ V. salmoninarum i.p. enjeksiyon yoluyla verilmiştir. Daha sonra eritromisin $(100 \mathrm{mg} / \mathrm{kg}$ canlı ağırlık/gün), florfenikol $(10 \mathrm{mg} / \mathrm{kg}$ canlı ağırlık/gün) ve amoksisillin $(80 \mathrm{mg} / \mathrm{kg}$ canlı ağırlık/gün) dozlarında antibiyotik uygulamaları yapılmıştır.

\section{Florfenikol uygulamasına ilişkin bulgular}

Deneysel enfeksiyonu takiben 3. günde saptanan belirtiler (uyuşukluk, yem almama ve stresli hareketler) florfenikol tedavisinin ilk 8 günü devam etti. 8. günden sonra balıkların durumunda iyileşme görüldü. Tedavi sonrasında, sadece 4 balıkta eksoftalmus ve renkte kararma saptandı. Tedavi sonrasında balıklardan TSA'ya yapilan ekimler sonucunda $V$. salmoninarum izole edilmemiştir. Bu gruptaki balıklarda ölüm kaydedilmemiştir (Tablo.2)

\section{Eritromisin uygulamasına ilişkin bulgular}

Deneysel enfeksiyon oluşturulan balıklarda bariz olarak ikinci günden itibaren uyuşukluk görülmeye başlandı, yem alımlarının azaldığı ve renkte koyulaşma başladığ gözlendi. Eritromisinle tedavinin 2. ve 3. gününde ölen 4 balıkta eksoftalmus, vücut boşluğunda sıvı birikimi, karaciğerde solgunluk, iç organlarda hemoraji, bağırsakta iltihaplı sıv1 saptandı. 4. günden sonra bu grupta kalan balık da ölüm görülmedi. Fakat 28 adet balıkta eksoftalmus ve renkte kararma belirtileri devam etti. Deneme sonunda kalan 36 balıktan yapılan ekimler sonucunda balıkların \%70'inden $V$. salmoninarum izole edildi (Tablo2). Balıklar enfeksiyon etkenini eritromisin uygulamasına rağmen taşıyorlardı ancak ölüm görülmedi.

\section{Amoksisiklin uygulamasına ilişkin bulgular}

$\mathrm{Bu}$ grupta ki balıklar amoksisiklin içeren yemlerle beslenmiştir. Hastalık belirtileri enjeksiyonu takiben 4. gün itibariyle iştahsızlık ve hareketlerde yavaşlama ve renkte kararma şeklinde başlamıştır. Tedavinin 4. gününde 2 adet balık ölmüştür. İlaçlı yem uygulamasının 5. günü itibariyle balıklarda iyileşmeler (yem alımında düzelme, daha aktif hareket etme) görülmeye başladı. 8. günde bu gruptaki balıkların sağlık durumunun diğer gruplara oranla iyi olduğu görüldü. Deneme sonu 24 adet balıkta hastalık belirtileri hala devam ediyordu. Deneme sonunda kalan 38 adet balıktan yapılan ekimler sonucunda balıkların \% 50'inden V. salmoninarum izole edildi (Tablo 2).

\section{Doksisiklin uygulamasına ilişkin bulgular}

V. salmoninarum enjeksiyonunu takiben klinik belirtiler olarak iştahsızlık, hareketlerde yavaşlama, renkte kararma ve stresli davranışlar saptanmıştır. Doksisiklin uygulamasının 6. gününden itibaren balıkların çoğunluğunda yem alımı, hareketleri ve vücut renkleri normale dönmüştür. Deneme sonrasında 6 adet balıkta renkte kararma ve eksoftalmus saptanmıştır. Bu gruptaki balıklarda ölüm kaydedilmemiştir. Tedavi sonrasında tüm balıklardan TSA'ya yapılan ekimler sonucunda $V$. salmoninarum izole edilmemiştir (Tablo.2). 


\section{Kontrol grubu}

Kontrol grubunda, V. Salmoninarum enjeksiyonu takiben, 3. günde baliklarda renkte koyulaşma, uyuşukluk, yem almama gibi belirtiler görülmeye başlanmıştır. Kontrol grubundaki balıklarda ölümler 3-20. günler arasında devam etmiş ve 40 adet balıktan 18 adedi ölmüş̧ür (Tablo 2). Bu süreçte balıklarda saptanan bulgular şiddetli eksoftalmus, alt ve üst çenede hemoraji, kuyruk yüzgecinde erime ve hemoraji, anüste prolapsus ve hemoraji, solungaçlarda solgunluk, yağ dokuda ve hava kesesinde nokta şeklinde kanama, karaciğer ve kasda peteşial hemorajiler, kalpte yaygın hemoraji, bazı balıklarda karaciğerde solgunluk, bazılarında ise karaciğerde hiperemi saptanmıştır. Kontrol grubunda hayatta kalan balıkların tamamından $V$. salmoninarum izole edilmiştir.

Tablo 2. Tedavi uygulamasında sonunda gruplardaki balık ölümleri, nispi hayatta kalma oranları ve hayatta kalan balıklarda $V$. salmoninarum'un izolasyonu (\%)

\begin{tabular}{ccccc}
\hline \hline Gruplar & Ö.B.S/T.B.S.* & $\begin{array}{c}\text { Ölüm Oranı } \\
(\%)\end{array}$ & RPS & $\begin{array}{c}\text { V.salmoninarum'un } \\
\text { reizolasyonu } \\
(\%)\end{array}$ \\
\hline Florfenikol & $0 / 40$ & 0 & 100 & 0 \\
Doksisiklin & $0 / 40$ & 0 & 100 & 0 \\
Amoksisillin & $2 / 40$ & 5 & 89 & 50 \\
Eritromisin & $4 / 40$ & 10 & 78 & 70 \\
Kontrol & $18 / 40$ & 45 & & 100 \\
\hline \hline * Ölen Balık Sayıs1/Toplam Balık Sayıs1
\end{tabular}

\section{TARTIŞMA ve SONUÇ}

Çalı̧̧mamızda deneysel olarak vagokokkozis hastalığının oluşturulmasını takiben balıklarda görülen renkte koyulaşma, uyuşukluk, yem almama, şiddetli eksoftalmus, alt ve üst çenede hemoraji, kuyruk yüzgecinde erime ve hemoraji, anüste prolapsus ve hemoraji, solungaçlarda solgunluk, karaciğer, yağ doku, hava kesesi ve kasdapeteşialhemorajiler, kalpte yaygın hemoraji, bazı balıklarda karaciğerde solgunluk ya da hiperemi belirtilerinin, daha önce yapılmış çalışmalardaki belirtiler ile benzer olduğu görülmüştür (Michel vd., 1997; Ruiz-Zarzuela vd., 2005; Didinen vd., 2011). Buna karşın, aynı araştırmacılar doğal olarak ortaya çıkmış vagokokkozis salgınlarında saptanan bazı klinik bulgular (operkular bölgenin arkasında ve kaudal bölgede frunkuller, kalp, karaciğer ve dalakta fibrinli bir katman, vücudun her iki yanında lezyonlar ve midede şeffaf sıvı birikimi) çalışmamız esnasında saptanmamıştır. Bu durum enfeksiyonun meydana geliş şeklinin ve şiddetinin, balık büyüklüğünün ve balıkların bulundukları ortam şartlarının farklı olmasından kaynaklanabilir.

$\mathrm{Bu}$ çalışmada, deneysel olarak oluşturulmuş vagokokkozisin tedavisinde florfenikol, eritromisin, doksisiklin ve amoksisillin uygulamalarının etkileri araştırılmıştır. Gruplarda tedavi süresince gözlenen klinik bulgular, kontrol grubu ile karşılaştırıldığında; florfenikol, amoksisillin ve doksisiklin gruplarında belirgin bir azalmanın olduğu, eritromisin grubunda ise tespit edilen belirtilerin, diğer antibiyotiklerle tedavi edilen balıktaklarda saptanan 
belirtilere göre daha fazla olduğu görülmüştür. Doksisiklinle tedavi yapılan balıklarda diğer antibiyotiklere göre çok daha hılı iyileşme görülmüştür.

Tedavi uygulamalarının sonunda kalan balıklarından yapılan bakteriyolojik ekimler sonucunda florfenikol ve doksisiklin gruplarında $V$. salmoninarum izole edilmemiştir. Ayrıca bu gruplarda tedavi esnasında balık ölümü görülmemiştir. Bu sonuç vagokokkozisin tedavisinde florfenikol ve doksisiklinin kullanılabileceğini göstermektedir. Benzer şekilde, daha önce yapılan bir çalışmada, doğal vagokokkozis enfeksiyonunun esnasında anaç gökkuşağı alabalıklarının tedavisinde florfenikolün başarılı olduğu gösterilmiştir (Tanrıkul vd., 2014). Çalışmamızdan farklı olarak, vagokokkozisle doğal olarak enfekte olmuş 1800$2200 \mathrm{~g}$ ağırlığındaki gökkuşağı alabalığı anaçlarının tedavisinde doksisiklinin 20 mg/dozunda 7 gün süreyle kullanımının başarısız olduğu bildirilmiştir (Didinen vd., 2011). $\mathrm{Bu}$ farklılık anaç balıkların enfeksiyona daha duyarlı olmalarından, anaç balıkların bu hastalığa yakalandıkları süreçte fotoperiyot havuzlarında bulunmaları, bakımlarının iyi olmaması nedeniyle, stresli şartlar altında olmaları, hastalığın daha şiddetli seyretmesi ve antibiyotiğin uygulama süresinin daha kısa olmasından kaynaklanabilir.

Tedavi denemesi sonunda eritromisin ve amoksisillin uygulamaları yapılan balıklarda, V. salmoninarum'un izolasyonu, balıkların tedavi sonrasında balıkların patojeni taşıyıcı durumda olduklarını göstermiştir. Ayrıca eritromisin grubu balıklarda \%5, amoksisillin grubu balıklarda \%10 oranında ölüm saptanmıştır. Amoksisillinin vagokokkozisin tedavisindeki başarısızlığı daha önce yapılan bir çalışmada daha kaydedilmiştir (Michel vd., 1997). Benzer şekilde, başka bir çalışmada, V. salmonarium suşlarının eritromisin ve oksitetrasiklin ile yapılan tedavilerinin sadece kısa periyotlar (5-7 gün) için etkili olduğu bildirilmiştir. Mortaliteleri azaltmak için ilaç tedavilerine devam edilmesinin gerekli olduğu, fakat bu durumun antibiyotiklere karşı direnç gelişme riskinin artışına neden olabileceği belirtilmiştir (Ruiz-Zarzuela vd., 2005). Bu nedenle eritromisin ve amoksisillinin, vagokokkozisin tedavilerinde kullanımlarının uygun olmadığ 1 görülmüştür.

Sonuç olarak, vagokokkozis hastalığının tedavisinde florfenikol $(10 \mathrm{mg} / \mathrm{kg}$ canlı ağırlık/gün) ve doksisiklin (20 mg/kg canlı ağırlık/gün) kullanımının başarılı sonuçlar verdiği görülmüştür.

\section{Alıntılama}

Kan A., Didinen B. I. 2016. Gökkuşağı Alabalıkları (Oncorhynchus mykiss, Walbaum 1792)'nda Vagokokkozise Karşı Etkili Antibakteriyel Tedavinin Belirlenmesi. Eğirdir Su Ürünleri Fakültesi Dergisi. 12(1), 41-48.

\section{KAYNAKLAR}

Austin, B., Austin, D.A. 2007. BacterialFishPathogens: Diseases of Farmedand Wild Fish, 4th edn, Springer-Praxis, Chichester, UK. ISBN 1402060688.

Didinen, B.I., Kubilay, A., Diler, Ö., Ekici, S., Onuk, E., Findik, A. 2011. First Isolation of Vagococcus salmoninarum fromCulturedRainbow Trout (Oncorhynchus mykiss, Walbaum) Broodstocks in Turkey. Bull. Eur. Ass. FishPathol., 31(6),235-243.

Ghittino, C.,Latini, M., Agnetti, F., Petracca, G. 2004. EmergingPathologies in Aquaculture: Effects on ProductionandFoodSafety. Atti XI ConvegnoNazionale S.I.P.I., 7-9 Ottobre 2004, Finale Ligure (SV) Italy, 37-39.

Michel, C.,Nougayrede, P., Eldar, A., Sochon, E., de Kinkelin, P. 1997. Vagococcus salmoninarum a Bacterium of PathologicalSignificance in Rainbow Trout Oncorhynchus mykiss Farming. Dis. Aquat. Org., 30, 199-208. 
Ruiz-Zarzuela, I., de Blas, I., Girones, O., Ghittino, C., Mùzquiz, J.L. 2005. Isolation of Vagococcus salmoninarum in Rainbow Trout Oncorhynchus mykiss (Walbaum), Broodstocks: Characterisation of thePathogen. Vet. Res. Commun., 29, 553-562.

Tanrıkul, T.,Avsever, M.L., Onuk, E.E., Didinen, B.I. 2014. Vagococcus salmoninarum a Causative Agent of Disease in Rainbow Trout (Oncorhynchus mykiss, Walbaum) Broodstocks in the Aegean Region of Turkey. Etlik Vet Mikrobiyol Derg, 25 (1), 11-16. 